\title{
Larva migrans within scalp sebaceous gland
}

\author{
Larva migrans em glândula sebácea do couro cabeludo
}

\author{
Lucinda Calheiros G uimarães, José Humberto Silva, Kaissor Saad, Edison Reis \\ Lopes and Antonio Carlos Oliveira Meneses
}

\begin{abstract}
A$ case of larva migrans or serpiginous linear dermatitis on the scalp of a teenager is reported. An ancylostomid larva was found within a sebaceous gland acinus. The unusual skin site for larva migrans as well as the penetration through the sebaceous gland are highlighted. The probable mechanism by which the parasite reached the skin adnexa is discussed.
\end{abstract}

Key-words: Cutaneous larva migrans. Scalp. Sebaceous gland. Ancylostoma.

Resumo Relata-se caso de larva migrans ou dermatite linear serpiginosa no couro cabeludo de adolescente, no qual o ancilostomídeo foi encontrado no interior de glândula sebácea. Destaca-se a possibilidade do helminto sediar-se em locais pouco usuais, das glândulas sebáceas serem via de penetração de larvas na pele e discute-se o provável mecanismo pelo qual o agente implantou-se no anexo cutâneo.

Palavras-chaves: Larva migrans cutânea. Couro cabeludo. Glândula sebácea. Ancylostoma.

Cutaneous larva migrans, also known as creeping eruption, is caused by small bowel dwelling helminths, usually Ancylostoma brasiliense. Dogs and cats are the natural reservoirs 6 . Human beings rarely are the final hosts5. The infective larvae on contact with human skin are able to perforate the epidermis but usually fail to reach the dermis6.

This report describes helminth larvae within a sebaceous gland as well as discusses how they were able to arrive to such a site.

\section{CASE REPORT}

This was a 12-year old, white, student, female from Uberaba, Minas Gerais State, Brazil, who owned a pet dog. Three months prior to the examination she had laid to rest on a river shore in the city of Rifaina, São Paulo State, Brazil. After some 20 days she noticed a bean-sized pruriginous, soft, superficial, right occipital scalp papule. The lesion was single, involutes spontaneously and, after some time, relapsed.
Pathology. Gross examination. Scalp patch measuring $1.3 \times 1.2 \mathrm{~cm}$ on the epidermal surface, without any changes in the cut surface. Subcutaneous thickness was $0.3 \mathrm{~cm}$. Microscopy (Figures 1, 2 and 3): Sections of scalp skin presented with an epidermal cavity between the prickle cell and horny layers and partly filled with eosinophilic debris as well as some polimorphonuclear neutrophils. There were

\footnotetext{
Faculdade de Medicina do Triângulo Mineiro, Hospital Hélio Angotti (Associação de Combate ao Câncer do Brasil Central) e Instituto de Ciências Biológicas e da Saúde da Universidade de Uberaba, Uberaba, MG.

Address to: Dr. Antonio Carlos Oliveira Meneses. Serviço de Patologia Cirúrgica da Faculdade de Medicina do Triângulo Mineiro. Rua Getúlio Guaritá, 130, Abadia. 38025-440 Uberaba, MG, Brasil. Fax: 55034 312-6640.

E-mail: aom@mednet.com.br

Recebido para publicação em 19/12/97.
} 


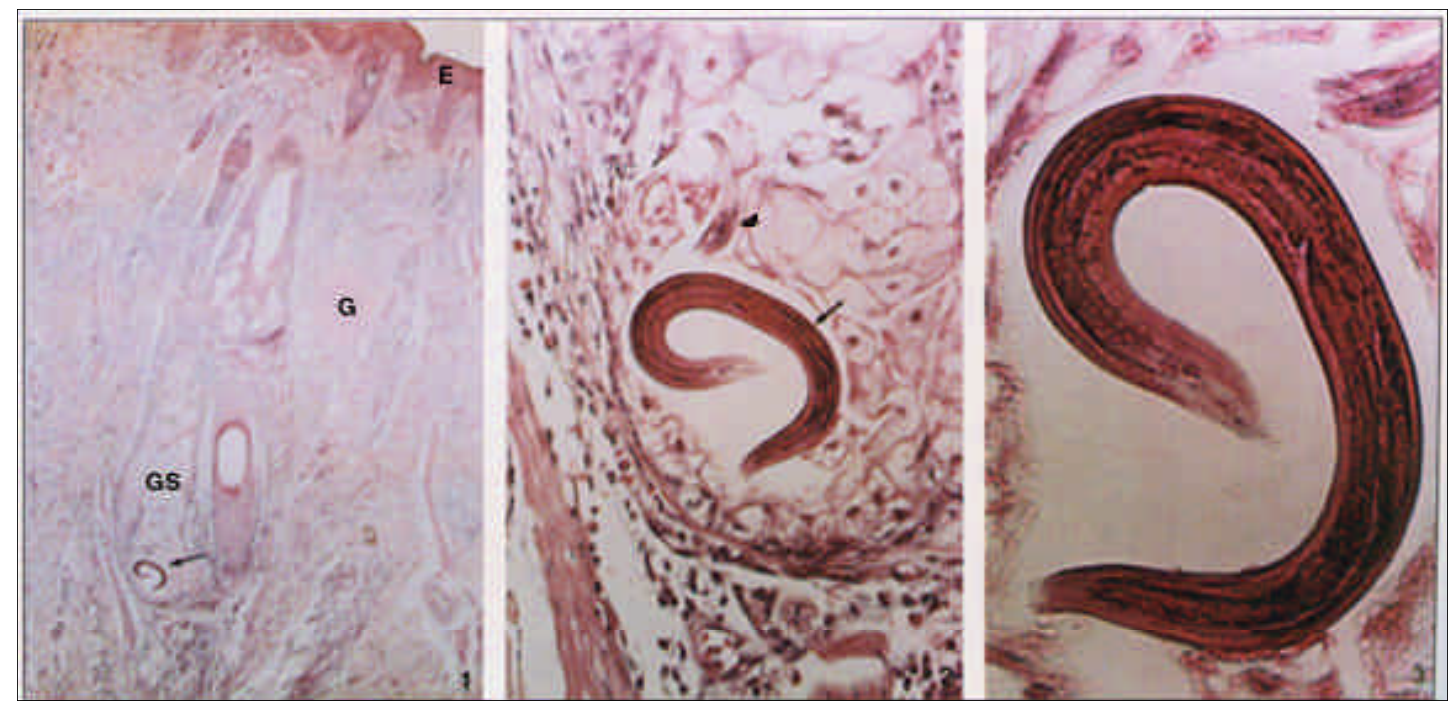

Figure 1 - Hematoxylin and eosin stained paraffin section of scalp skin showing helminth larva within a sebaceous gland (GS). E = epidermis; $D=$ dermis $(x 25,5)$.

Figure 2 - Two helminth larvae (arrow and arrow-head) within scalp sebaceous gland (higher magnification of the Figure 1; 127,5).

Figure 3 - Higher magnification of the helminth larva point with arrow-head in Figure 2. The esophageal shape and the esophageal-intestinal junction are consistent with those of an infective larva of Ancylostoma sp (x255).

moderate spongiosis and elongation of rete ridges. The dermal blood capillaries had thick walls. There were peri-capillary infiltration of limphocytes, macrophages and eosinophils. There is also slight diffuse interstitial edema. Nearly longitudinal sections of helminth larva were found in a sebaceous gland. Some parts of the larva were missing. The head and the entire esophagus could be seen. The following measures were taken: maximum width 20 micrometers, nerve ring from anterior end 75 micrometers, lenght of the esophagus 140 micrometers. Under oil immersion objective double lateral cuticular alae were noted. From the way the sections of the larva lies in the tissues, it is estimated that the larva is at least 550 micrometers long and is probably more than 600 micrometers. All of this features as well as the shape of the esophagus and the esophageal-intestinal junction are consistent with those of an infective larva of the genus Ancylostoma. The sections also showed within the same sebaceous gland a small part of a second apparently dead helminth larva. Linphocytes, macrophages and eosinophils infiltrate around the sebaceous gland hair follicle. Sweat glands and hair muscles are unremarkable. Dilated blood capillaries, edema and eosinophils are found within the subcutaneous fat tissue.

\section{DISCUSSION}

Pathology showing cutaneous Ancylostoma larvae is consistent with larva migrans. In spite of a cavity found between the horny and the malpighian layers of the epidermis a winding skin tract was not clinically described. Such cavity is the microscope representative of the creeping eruption. Perhaps the eruption itself was hidden under the abundant local hairs. This report demonstrates an unusual site for larva migrans such as the scalp as well as highlights sebaceous glands as a probable way of skin penetration of larvae beyond hair follicle.
Experience with dogs 8 have shown A. brasiliense larvae crossing the epidermal horny layer, migrating initially parallel to the skin surface and, later on, into the live layers of the epidermis and reaching the hair follicles through their external roothsheat. That study also showed dermal and subcutaneous penetration of larvae through either sebaceous or apocrine glands. According to Nikolaides et al 4 , the genus Ancylostoma larvae are usually unable to reach beyond human epidermis, hair follicles or its glands. Those larvae present with hyaluronidase ${ }^{2}$ and collagenase $^{3}$ 
activities. It likely that such activities are not adequate to open tracks through the human dermis. The invasiveness is limited to the several epithelial compartiments of the human skin. A condensed fibrous layer enseathes the normal human hair follicle 1 . Therefore, for Ancylostoma larvae, sebaceous and apocrine glands are suspect to be easiest way out of human hair follicle into the deep skin. In addition, this way of larva migration might be favoured as sebaceous gland cells are full of soft lipids and tore open when mature?.

\section{ACKNOWLEDGEMENTS}

We are greatful to Professor M. Dale Little (Tulane University Medical Center) for his precious help in identifying the larvae.

\section{REFERENCES}

1. Ackerman $A B$, Chongchitnaut N, Sanchez J, Guo $Y$, Bennin B, Reichel M, Randall MB. Embryologic, histologic and anatomic aspects. In: Ackerman $A B$, Chongchitnaut N, Sanchez J, Guo Y, Bennin B, Reichel M, Randall MB (eds) Histologic diagnosis of inflamatory skin diseases, 2nd edition, Williams \& Wilkins, Baltimore, p.33, 1997.

2. Hotez PJ, Narasimhan S, Haggerty J, Milstone L, Bhopale V, Schad GA, Richards FF. Hyaluronidase from infective Ancylostoma hookworm larvae and its possible function as a virulence factor in tissue invasion and in cutaneous larva migrans. Infection and Immunity 60:10181023, 1992.

3. Meyers WM, Neafie RC. Creeping eruption. In: Binford $\mathrm{CH}$, Connor DH (eds) Pathology of tropical and extraordinary diseases. Armed Forces Institute of Pathology, Washington, DC, vol II, p. 437-439, 1976.

4. Nikolaides G, Rosen T. Cutaneous larva migrans. In: Connor DH, Chandler FW, Schwartz DA, Manz HJ, Lac
EE (eds) Pathology of infectious diseases. Appleton \& Lange, Stanford, Connecticut, vol II, p. 1455-1457, 1997.

5. Orihel TC, Ash LR. Parasites in human tissues. American Society of Clinical Pathology Press, Chicago, p. 116, 1995.

6. Rey L. Larva migrans cutânea e visceral. In: Rey L (ed) Parasitologia, $2^{\mathrm{a}}$ edição, Guanabara Koogan, Rio de Janeiro. p. 532-536, 1991.

7. Stenn KS, Bhawan J. The normal histology of the skin. In: Farmer ER, Hood AF (eds) Pathology of the Skin. Appleton \& Lange, Norwalk, Connecticut, p. 22, 1990.

8. Vetter JC, van der Linden ME. Skin penetration of infective hookworm larvae. I. The path of migration of infective larvae of Ancylostoma braziliense in canine skin. Zeitschrift fur Parasitenkunde 53:255-262,1977. 